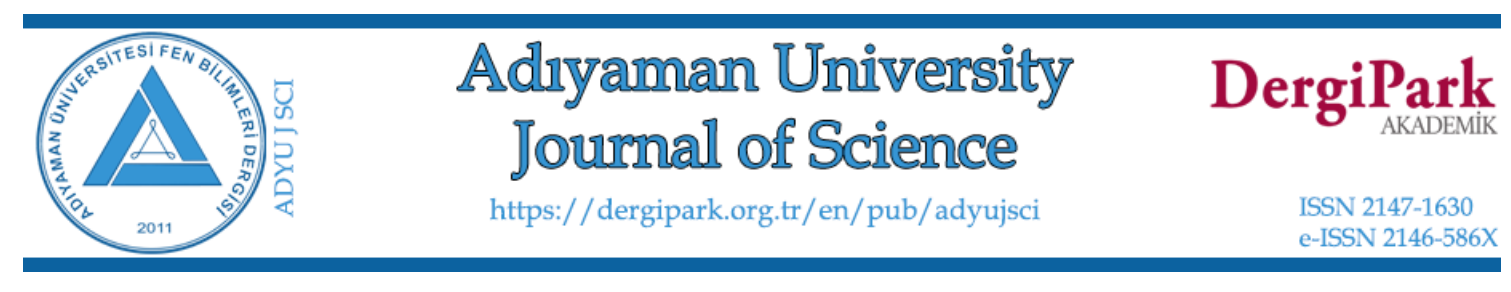

\title{
Cladocera and Copepoda (Crustacea) Fauna of Balya District (Balıkesir/Turkey)
}

\author{
Süleyman ÇOLAK ${ }^{1}$, Alp ALPER ${ }^{2, *}$ \\ ${ }^{I}$ Balya Atatürk Multi-Program Anatolian High School, Balya, Balıkesir, Turkey \\ suleymann88@gmail.com,ORCID: 0000-0001-5903-7551 \\ ${ }^{2}$ Balıkesir University, Faculty of Science and Literature, Department of Biology, Çağış Campus, \\ Balıkesir, Turkey \\ alpalper80@gmail.com,ORCID: 0000-0001-5507-4072
}

\begin{abstract}
In this study, a total of 35 stations including troughs, ponds and streams were sampled between November 2017 and July 2018 in order to determine the Cladocera and Copepoda (Crustacea) fauna of Balya. As a result, a total of 37 species were determined, 21 from Cladocera and 16 from Copepoda. Based on the previous studies, it has been determined that 34 species are recorded for the first time from study area besides 13 species are also determined as new records for Balıkesir fauna.
\end{abstract}

Keywords: Cladocera; Copepoda; Balya; Balıkesir; Fauna.

\section{Balya İlçesinin (Balıkesir/Türkiye) Cladocera ve Copepoda (Crustacea) Faunası}

\section{$\ddot{O} \mathbf{z}$}

Bu çalışmada, Balya'nın Cladocera ve Copepoda (Crustacea) faunasını belirlemek için yalak, gölet ve akarsuların içinde olduğu toplam 35 istasyon Kasım 2017 ile Temmuz 2018 tarihleri arasında örneklendi. Sonuç olarak 21'i Cladocera'dan, 16'sı Copepoda'dan olmak üzere

\begin{tabular}{l}
\hline \hline * Corresponding Author \\
(c) (i) ()
\end{tabular}


toplam 37 tür belirlendi. Önceki çalışmalara incelendiğinde 34 türün çalışma alanından ilk kez kaydedildiği, üstelik 13 türün de Balıkesir faunası için yeni kayıt olduğu tespit edildi.

Anahtar Kelimeler: Cladocera; Copepoda; Balya; Balıkesir; Fauna.

\section{Introduction}

Zooplankton occupies a central position in the pelagic food web, transferring carbon and energy from primary producers to higher trophic levels, and potentially suppressing the abundance of phytoplankton. Cladocerans and copepods are small crustaceans and also the most important members of freshwater zooplankton. They are colonized in any kind of freshwater aquatic body (troughs, ponds, lakes, dams, rivers, etc.) and some other wet habitats (leaf litter, sphagnum mat, caves, tree holes, etc.) [1-3].

The diversity of global freshwater cladocerans and copepods is around 620 and 2814 species respectively $[4,5]$. However, the richness of actual species is estimated to be 2-4 times higher [6-8]. Compared to other zoogeographical regions, the Cladocera and Copepoda fauna of the Palearctic is quite rich; 245 cladoceran and 1204 copepod species which is more than twice the number recorded for other regions have been recorded $[4,8,9]$. Biodiversity of the Copepoda and Cladocera fauna of Turkey is over than 240 [9].

Balya district is located in the northwest of Balıkesir. In terms of surface area, it is ranked as 5th with $952 \mathrm{~km}^{2}$ among the 20 districts of the province. $70 \%$ of the surface of Balya is mountainous, the rest is rugged terrain. The highest point is Akçal Hill $(642 \mathrm{~m}$.) located in the east. Animal husbandry is the main source of income due to the rough geography of Balya; therefore, many troughs were built for the livestock. Although suitable land is limited, agricultural activities are also carried out in the district; dams and ponds were built to provide the water needed in irrigation [10].

Although being rich in freshwater resources, Cladocera and Copepoda fauna of Balya have not been researched much so far. The only record in the literature was 3 copepod species which were given from Ilıca pond by Sönmez et al. [11]. So, 35 freshwater resources were sampled in this study in order to reveal Cladocera and Copepoda fauna of Balya.

\section{Materials and Methods}

The samples were collected from 35 stations (Fig. 1.) for 4 times between November 2017 and July 2018 with a help of $60 \mu \mathrm{m}$ mesh sized plankton net and/or hand net. The localities of the stations are given in Table 1. Geographical data (altitude and 
coordinates) were obtained by using a Magellan eXplorist 610 GPS device. Collected samples were immediately preserved with $70 \%$ ethanol. Cladocerans and copepods were extracted from detritus using a Pasteur pipette under an OLYMPUS SZX-16 stereomicroscope. Extracted specimens were stored in $70 \%$ ethanol. Specimens were prepared by using the method described by Karaytuğ and Sak [12] and were identified under an OLYMPUS BX-50 microscope equipped with a differential interference contrast attachment. Specimens were identified according to Błędzki and Rybak [2], Rogers and Thorp [3], Einsle [13], Ueda and Reid [14], Wells [15], and relevant other literature.

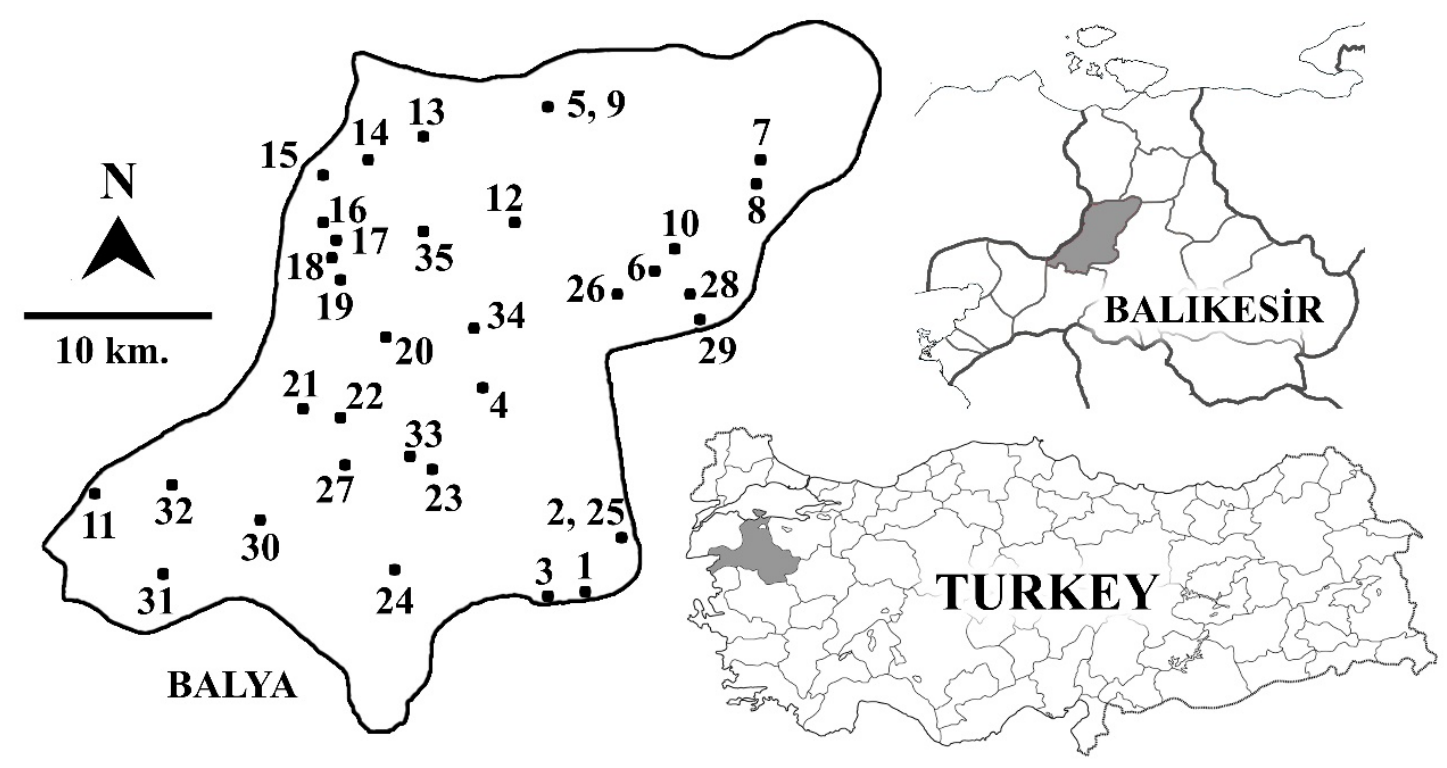

Figure 1: Sampling stations

Table 1: The localities of the stations

\begin{tabular}{cccccc}
\hline $\begin{array}{c}\text { Station } \\
\text { number }\end{array}$ & Locality & Type & \multicolumn{2}{c}{ Coordinate } & \multicolumn{2}{c}{$\begin{array}{c}\text { Altitude } \\
(\mathbf{m} .)\end{array}$} \\
\hline 1 & Hacı Hüseyin & Pond & $39.67911^{\circ} \mathrm{N}$ & $27.66990^{\circ} \mathrm{E}$ & 235 \\
2 & Ali Demirci I & Pond & $39.70834^{\circ} \mathrm{N}$ & $27.69579^{\circ} \mathrm{E}$ & 269 \\
3 & Koca Avşar & Pond & $39.67231^{\circ} \mathrm{N}$ & $27.64349^{\circ} \mathrm{E}$ & 204 \\
4 & Kadiköy & Stream & $39.77906^{\circ} \mathrm{N}$ & $27.60736^{\circ} \mathrm{E}$ & 140 \\
5 & Koyuneri I & Stream & $39,91401^{\circ} \mathrm{N}$ & $27.64855^{\circ} \mathrm{E}$ & 110 \\
6 & Kayalar I & Trough & $39.83604^{\circ} \mathrm{N}$ & $27.71619^{\circ} \mathrm{E}$ & 171 \\
7 & Ilica I & Pond & $39.88944^{\circ} \mathrm{N}$ & $27.78119^{\circ} \mathrm{E}$ & 145 \\
8 & Ilica II & Trough & $39.87789^{\circ} \mathrm{N}$ & $27.77909^{\circ} \mathrm{E}$ & 118 \\
9 & Koyuneri II & Trough & $39.91472^{\circ} \mathrm{N}$ & $27.64840^{\circ} \mathrm{E}$ & 121 \\
\hline
\end{tabular}




\begin{tabular}{|c|c|c|c|c|c|}
\hline \multirow{2}{*}{$\begin{array}{c}\begin{array}{c}\text { Station } \\
\text { number }\end{array} \\
10\end{array}$} & \multirow{2}{*}{$\frac{\text { Locality }}{\text { Between Ilıca and Kayalar }}$} & \multirow{2}{*}{$\begin{array}{c}\text { Type } \\
\text { Stream }\end{array}$} & \multicolumn{2}{|c|}{ Coordinate } & \multirow{2}{*}{$\begin{array}{c}\begin{array}{c}\text { Altitude } \\
(\mathbf{m} .)\end{array} \\
146\end{array}$} \\
\hline & & & $39.84483^{\circ} \mathrm{N}$ & $27.72702^{\circ} \mathrm{E}$ & \\
\hline 11 & Farsak & Pond & $39.73061^{\circ} \mathrm{N}$ & $27.36464^{\circ} \mathrm{E}$ & 530 \\
\hline 12 & Ören & Trough & $39.85882^{\circ} \mathrm{N}$ & $27.62700^{\circ} \mathrm{E}$ & 270 \\
\hline 13 & Değirmendere & Trough & $39.90061^{\circ} \mathrm{N}$ & $27.57063^{\circ} \mathrm{E}$ & 177 \\
\hline 14 & Mancınık & Trough & $39.88962^{\circ} \mathrm{N}$ & $27.53625^{\circ} \mathrm{E}$ & 189 \\
\hline 15 & Dereköy I & Trough & $39.88034^{\circ} \mathrm{N}$ & $27.50861^{\circ} \mathrm{E}$ & 206 \\
\hline 16 & Dereköy II & Trough & $39.85821^{\circ} \mathrm{N}$ & $27.50773^{\circ} \mathrm{E}$ & 267 \\
\hline 17 & Kara Mustafa I & Trough & $39.84784^{\circ} \mathrm{N}$ & $27.51548^{\circ} \mathrm{E}$ & 352 \\
\hline 18 & Kara Mustafa II & Trough & $39.84295^{\circ} \mathrm{N}$ & $27.51332^{\circ} \mathrm{E}$ & 344 \\
\hline 19 & Kara Mustafa III & Trough & $39.83192^{\circ} \mathrm{N}$ & $27.51980^{\circ} \mathrm{E}$ & 432 \\
\hline 20 & Çalova & Trough & $39.80316^{\circ} \mathrm{N}$ & $27.54534^{\circ} \mathrm{E}$ & 313 \\
\hline 21 & Doğanlar & Trough & $39.76819^{\circ} \mathrm{N}$ & $27.49594^{\circ} \mathrm{E}$ & 432 \\
\hline 22 & Doğanlar-Balya Road & Trough & $39.76535^{\circ} \mathrm{N}$ & $27.51775^{\circ} \mathrm{E}$ & 316 \\
\hline 23 & Balya & Trough & $39.74380^{\circ} \mathrm{N}$ & $27.57519^{\circ} \mathrm{E}$ & 282 \\
\hline 24 & Göktepe & Trough & $39.69258^{\circ} \mathrm{N}$ & $27.55242^{\circ} \mathrm{E}$ & 391 \\
\hline 25 & Ali Demirci II & Irrigation canal & $39.70834^{\circ} \mathrm{N}$ & $27.69579^{\circ} \mathrm{E}$ & 269 \\
\hline 26 & Kayalar II & Pond & $39.82528^{\circ} \mathrm{N}$ & $27.69250^{\circ} \mathrm{E}$ & 200 \\
\hline 27 & Müstecap I & Trough & $39.74285^{\circ} \mathrm{N}$ & $27.52187^{\circ} \mathrm{E}$ & 251 \\
\hline 28 & Karlık & Trough & $39.82357^{\circ} \mathrm{N}$ & $27.73755^{\circ} \mathrm{E}$ & 214 \\
\hline 29 & Söbücealan & Trough & $39.81339^{\circ} \mathrm{N}$ & $27.74378^{\circ} \mathrm{E}$ & 245 \\
\hline 30 & Çiğdem & Trough & $39.71608^{\circ} \mathrm{N}$ & $27.46836^{\circ} \mathrm{E}$ & 350 \\
\hline 31 & Çamavşar-Çamucu & Trough & $39.69064^{\circ} \mathrm{N}$ & $27.40945^{\circ} \mathrm{E}$ & 487 \\
\hline 32 & Çarmık-Yaylacık & Trough & $39.73197^{\circ} \mathrm{N}$ & $27.41420^{\circ} \mathrm{E}$ & 466 \\
\hline 33 & Müstecap II & Trough & $39.74618^{\circ} \mathrm{N}$ & $27.56528^{\circ} \mathrm{E}$ & 303 \\
\hline 34 & Semiz-Çukurcak & Trough & $39.80881^{\circ} \mathrm{N}$ & $27.60152^{\circ} \mathrm{E}$ & 366 \\
\hline 35 & Göloba & Trough & $39.85377^{\circ} \mathrm{N}$ & $27.57118^{\circ} \mathrm{E}$ & 498 \\
\hline
\end{tabular}

\section{Results}

A total of 37 species were determined, composed of 21 cladocerans and 16 copepods. Identified species and its distribution to the stations and samplings are given in Table 2.

Table 2: Identified species and its distribution to the stations and samplings

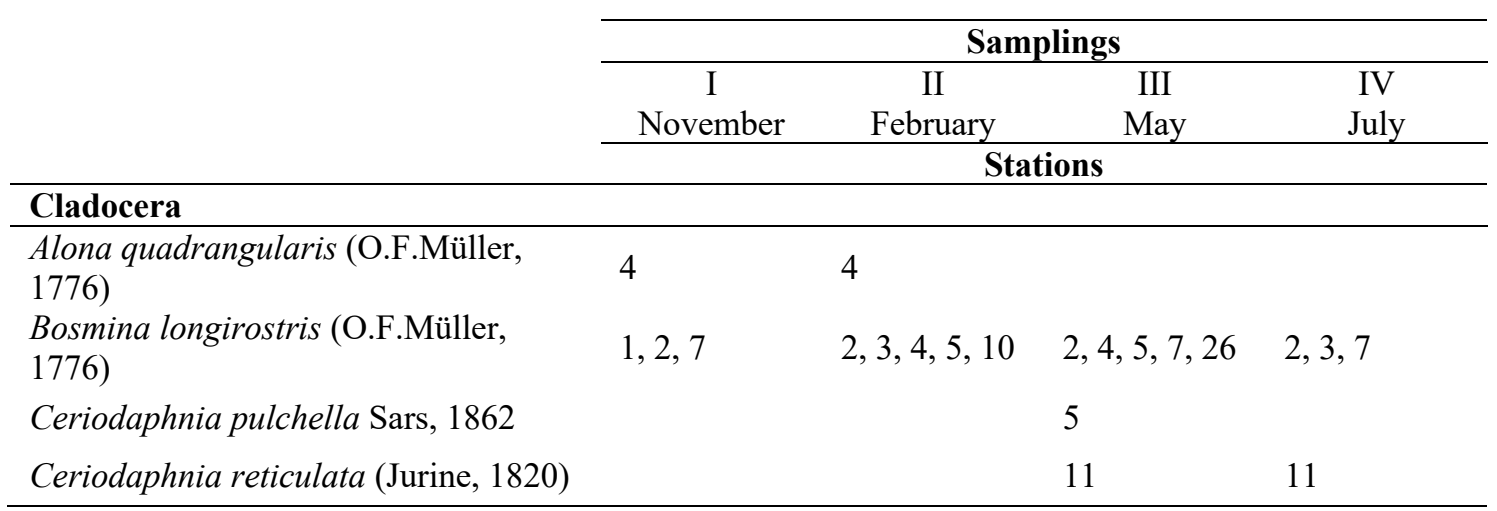




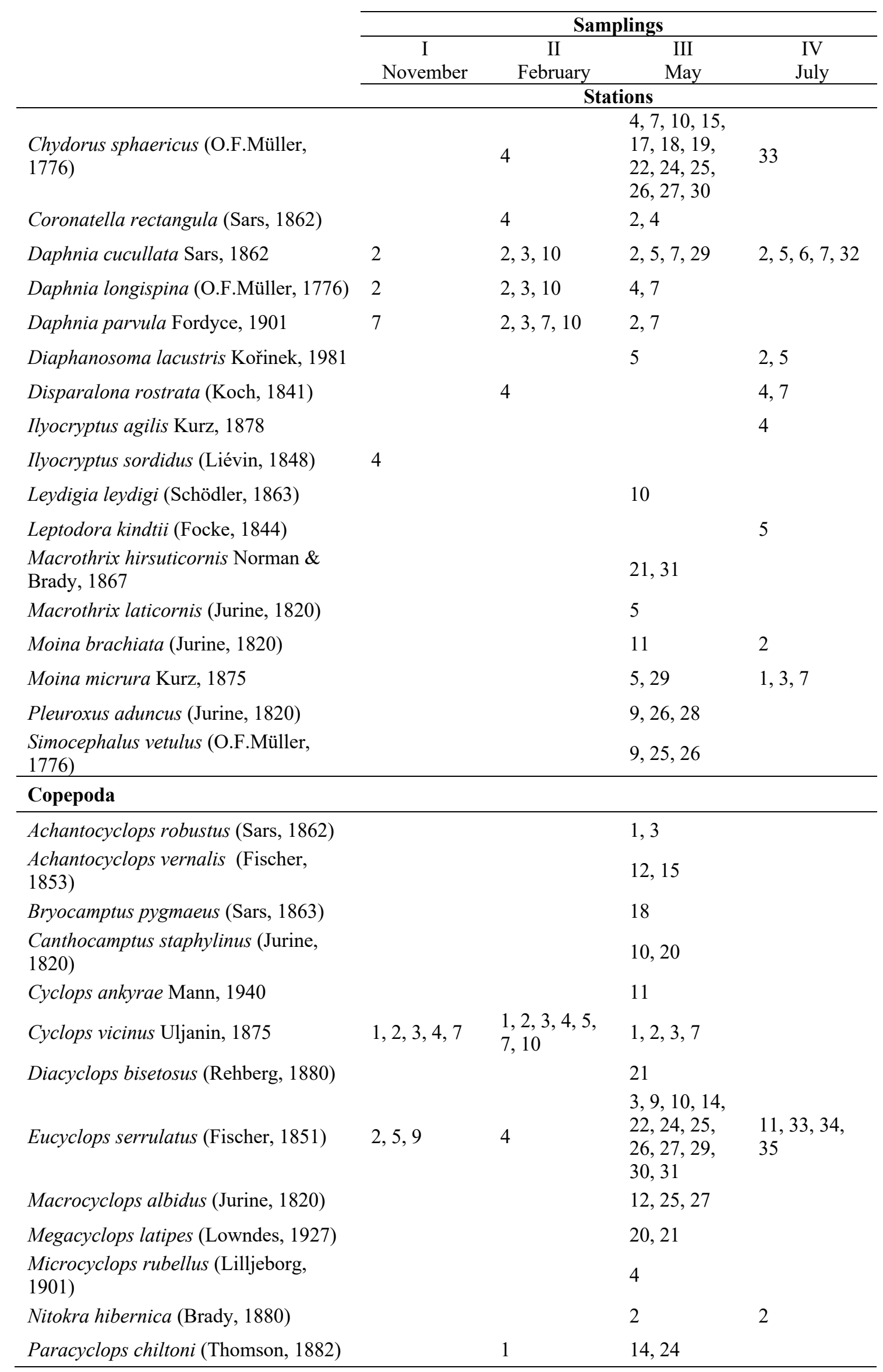




\begin{tabular}{|c|c|c|c|c|}
\hline & \multicolumn{4}{|c|}{ Samplings } \\
\hline & I & II & III & IV \\
\hline & November & February & May & July \\
\hline & \multicolumn{4}{|c|}{ Stations } \\
\hline Paracyclops fimbriatus (Fischer, 1853) & & & 22 & 6 \\
\hline $\begin{array}{l}\text { Thermocyclops oithoinides (Sars, } \\
\text { 1863) }\end{array}$ & 7 & & $2,4,5,7$ & $\begin{array}{l}1,2,3,4,5 \\
6,7,11,32\end{array}$ \\
\hline Tropocylops prasinus (Fischer, 1860) & 9 & & $\begin{array}{l}10,22,24, \\
26,27,28, \\
29,30\end{array}$ & $6,11,33,34$ \\
\hline
\end{tabular}

\section{Discussion}

Analysis of the literature was revealed that the Copepoda fauna of Balya has not been examined sufficiently. The only record in the literature was 3 species (A. robustus, E. serrulatus, and T. prasinus) which were given from Ilıca pond by Sönmez et al. [11]. No record was found in the literature about Cladocera fauna of Balya. So, all taxa identified from the district except 3 copepod species reported previously are new records. In Cladocera, C. sphaericus was the most common species followed by B. longirostris and D. cucullata. In Copepoda, E. serrulatus was the most common species followed by T. prasinus. It is determined that 13 species are specific to the stations where they are identified (Table 2.).

Turkey is divided into 25 river basins that correspond with its hydrological features by the General Directorate of State Hydraulic Works (GDSH -DSI in Turkish-) [16, 17]. Balıkesir is in the coverage of 3 basins; Marmara, North Aegean and Susurluk. Therefore, many water bodies fed by different streams have spread throughout the province, but only few of them have been studied. A total of 68 species, including 37 cladocerans and 31 copepods were recorded from various water resources (İkizcetepeler Dam Lake, Çaygören Dam Lake, Manyas Dam Lake, Manyas Lake, Gönen Stream) of Balıkesir [11, 18-33]. It is noteworthy that Lake Manyas was studied [18-25] more intensively than other places, 19 species were reported from the lake. A total of 13 species, 6 of the Cladocera (Ceriodaphnia pulchella, Daphnia parvula, Diaphanosoma lacustris, Ilyocryptus agilis, Ilyocryptus sordidus, and Macrothrix hirsuticornis) and 7 of the Copepoda (Canthocamptus staphylinus, Cyclops ankyrae, Diacyclops bisetosus, Megacyclops latipes, Microcyclops rubellus, Paracyclops fimbriatus, and Thermocyclops 
oithoinides) identified in our study have not been recorded previously from the province; therefore, they are new records for Balıkesir fauna.

\section{Acknowledgement}

We would like to thank Eray ERSOY (MSc) for his help in sampling. This study was part of an MSc thesis supervised by Dr. Alp ALPER.

\section{References}

[1] Havens, K.E., Zooplankton structure and potential food web interactions in the plankton of a subtropical chain-of-lakes, The Scientific World Journal, 2, 926-942, 2002.

[2] Błędzki, L.A., Rybak, J. I., Freshwater crustacean zooplankton of Europe, Cladocera \& Copepoda (Calanoida, Cyclopoida) Key to species identification, with notes on ecology, distribution, methods and introduction to data analysis, Springer International Publishing, Switzerland, 2016.

[3] Rogers, D.C., Thorp, J. H., Keys to Palaearctic fauna, Thorp and Covich's freshwater invertebrates - Volume IV, Elsevier, United Kingdom, 2019.

[4] Boxshall, G.A., Defaye, D., Global diversity of copepods (Crustacea: Copepoda) in freshwater, In: Freshwater animal diversity assessment, Balian, E.V., Lévêque, C., Segers, H., Martens, K. (eds), Springer, pp. 195-207, 2007.

[5] Smirnov, N.N., Physiology of the Cladocera, Academic Press, United Kingdom, 2017.

[6] Humes, A.G., How many copepods?, Hydrobiologia, 293, 1-7, 1994.

[7] Adamowicz, S.J., Purvis, A., How many branchiopod crustacean species are there? Quantifying the components of underestimation, Global Ecology and Biogeography, 14 (5), 455 468, 2005.

[8] Forró, L., Korovchinsky, N.M., Kotov, A.A., Petrusek, A., Global diversity of cladocerans (Cladocera; Crustacea), In: Freshwater animal diversity assessment, Balian, E. V., Lévêque, C., Segers, H., Martens, K. (eds), Springer, pp. 177-184, 2007.

[9] Ustaoğlu, M.R., An updated zooplankton biodiversity of Turkish inland waters, LimnoFish, 1 (3), 151-159, 2015.

[10] Aydın, İ., Madencilik-şehirleşme ilişkisine farklı bir örnek: Balya, Marmara Coğrafya Dergisi, 12, 133-147, 2006.

[11] Sönmez, S., Serdar, S., Alper, A., Karaytuğ, S., A faunistic study on the freshwater Copepoda (Crustacea) of Balıkesir, Journal of Applied Biological Sciences, 2 (3), 45-49, 2008.

[12] Karaytuğ, S., Sak, S., A contribution to the marine harpacticoid (Crustacea, Copepoda) fauna of Turkey, EU Journal of Fisheries \& Aquatic Sciences, 23 (3-4), 403-405, 2006. 
[13] Einsle, U., Copepoda: Cyclopoida: Genera Cyclops, Megacyclops, Acanthocyclops, SPB Academic Publishing, United Kingdom, 1996.

[14] Ueda, H., Reid, J. W., Copepoda: Cyclopoida: Genera Mesocyclops and Thermocyclops, SPB Academic Publishing, United Kingdom, 2003.

[15] Wells, J.B.J., An annotated checklist and keys to the species of Copepoda Harpacticoida (Crustacea), Zootaxa, 1568 (1), 1-872, 2007.

[16] Delipınar, Ş., Karpuzcu, M., Policy, legislative and institutional assessments for integrated river basin management in Turkey, Environmental Science \& Policy, 72, 20-29, 2017.

[17] Uzun, O., Dilek, F., Çetinkaya, G., Erduran, F., Açıksöz, S., National and regional landscape classification and mapping of Turkey: Konya closed basin, Suğla Lake and its surrounding area, International Journal of the Physical Sciences, 6 (3), 550-565, 2011.

[18] Noodt, W., Copepoda, Harpacticoidea aus dem limnischen mesopsammal der Türkei, İstanbul Üniversitesi Fen Fakültesi Hidrobiyoloji Araştırma Enstitüsü Yayınları, 2 (1), 27-40, 1954.

[19] Kiefer, F., Freilebende ruderfusskrebse (Crustacea, Copepoda) aus Türkischen binnengewassern, II Cyclopoida und Harpacticoida, İstanbul Üniversitesi Fen Fakültesi Hidrobiyoloji Araştırma Enstitüsü Yayınları, 2 (4), 108-132, 1955.

[20] Demirhindi, Ü., The preliminary planktonic investigations in the coastal lagoons and several brackish water lakes of Turkey, İ. Ü. Fen Fak. Mec., 37 (3-4), 205-232, 1972.

[21] Ustaoğlu, M., Balık, S., Kuş Gölü (Bandırma) zooplanktonu, Ulusal Biyoloji Kongresi, Erzurum, pp. 11-19, 1990.

[22] Gündüz, E., Türkiye içsularında yaşayan Cladocera (Crustacea) türlerinin listesi, Turkish Journal of Zoology, 21 (1), 37-45, 1997.

[23] Akbulut, N., Akbulut, A., The planktonic organisms of lake Manyas, Hacet. Bull. Nat. Sci. Eng., 29, 9-23, 2000.

[24] Türkmen, E.I. (2018). Manyas Kuş Gölü'nün zooplankton kommunite yapısı, Balıkesir University, Balıkesir/Turkey.

[25] Çelik, K., Manyas (Kuş) Gölü (Balıkesir) plankton ekolojisi, 2 Uluslararası Bandırma ve Çevresi Sempozyumu, Bandırma/Balıkesir, pp. 191-199, 2019.

[26] Alper, A., Çelebi, E., Çam, H., Karaytuğ, S., Cladocera and Copepoda (Crustacea) fauna of İkizcetepeler Dam Lake (Ballkesir, Turkey), Turkish Journal of Fisheries and Aquatic Sciences, 7 (1), 71-73, 2007.

[27] Bozkurt, A., Çelik, K., Sevindik, T.O., Seasonal variations in the length of zooplankton related to certain physicochemical variables in two freshwater reservoirs, Crustaceana, 85 (4-5), 447-462, 2012. 
[28] Ustaoğlu, M.R., Özdemir Mis, D., Aygen, C., Observations on zooplankton in some lagoons in Turkey, J. Black Sea/Mediterranean Environment, 18 (2), 208-222, 2012.

[29] Giritlioğlu, E. (2013). Manyas Barajı zooplankton ekolojisi, Balıkesir University, Balikesir/Turkey.

[30] Gürleyen, N., Ustaoğlu, M. R., Zooplankton fauna and seasonal changes of constructed ponds and reservoirs of Gönen Stream (Balıkesir-Turkey), Journal of Limnology and Freshwater Fisheries Research, 3 (2), 79-89, 2017.

[31] Çelik, K., Giritlioğlu, E., Zooplanktonik organizmaların Manyas Barajında (Balıkesir) mevsimsel değişimi ve bazı fiziksel ve kimyasal parametrelerle olan ilişkileri, Iğdır Üniversitesi Fen Bilimleri Enstitüsü Dergisi, 7 (2), 65-72, 2017.

[32] Bulut, H., Saler, S., Seasonal variations in zooplankton community of an aquatic ecosystem at Susurluk Basin (Balıkesir-Turkey), Fresenius Environmental Bulletin, 27 (4), 2530 $2535,2018$.

[33] Çelik, K., Bozkurt, A., Sevindik, T.O., Seasonal dynamics of the zooplankton community in the temperate eutrophic Çaygören Reservoir (Balıkesir), Turkey related to certain physicochemical parameters of water, Turkish Journal of Fisheries and Aquatic Sciences, 19 (6), 503-512, 2019. 